\title{
An empirical analysis of foreign direct investment and economic growth in Bangladesh
}

\author{
Shahjahan Ali ${ }^{1}$, Md. Rukunujjaman ${ }^{1}$, Khandaker Jahangir Alam ${ }^{2}$ \\ ${ }^{1}$ MSS student, Department of Economics, Begum Rokeya University, Rangpur, Bangladesh \\ ${ }^{2}$ Assistant Professor, Department of Economics, Begum Rokeya University, Rangpur, Bangladesh \\ Email address: \\ sabrur_eco@yahoo.com (S. Ali), himu05rzs@gmail.com (M. Rukunujjaman), nirob_eco_ru@yahoo.com (K. J. Alam)
}

\section{To cite this article:}

Shahjahan Ali, Md. Rukunujjaman, Khandaker Jahangir Alam. An Empirical Analysis of Foreign Direct Investment and Economic Growth in Bangladesh. International Journal of Business and Economics Research. Vol. 4, No. 1, 2015, pp. 1-10. doi: 10.11648/j.ijber.20150401.11

\begin{abstract}
Foreign Direct Investment (FDI) is assumed to benefit a poor country like Bangladesh, not only by supplementing domestic investment, but also in terms of employment creation, transfer of technology, increased domestic competition and other positive externalities. This paper focuses on the FDI-led growth hypothesis in the case of Bangladesh. The study is based on time series data from 1973 to 2013 . The econometric framework of cointegration and error correction mechanism were used to capture two way linkages between variables interest. It is evident in the results that the regression analyses do not provide much support for the view of a robust link between FDI and growth in Bangladesh. It does not imply that FDI is insignificant. Rather, its analysis reduces the confidence in the belief that FDI has exerted an independent growth effect in Bangladesh. But net attitudes of the civil society on the impact of FDI on opportunities for domestic business and economic activities is positive and net attitudes of foreign firms toward FDI reveals that the investment climate has not improved in Bangladesh as a result of lack of good governance, corruption, political instability and disturbance, bureaucratic inertia, and poor low and order situation
\end{abstract}

Keyword: Foreign Direct Investment, Economic Growth, Cointegration, Granger Causality, Bangladesh

\section{Introduction}

Foreign Direct Investment (FDI) can be defined long term investment of a "parent" "host" economy. FDI flows include assets, property (e.g. parent company technology, branding, and skills) and $\backslash$ or capital investment (greater than $10 \%$ of total shares in a company), reinvested earnings (retained profits in an affiliate, or intra company loan / debt transaction (long term borrowing/ lending) between firm and affiliate enterprises. FDI stocks are the value of capital and reserves (including retained profit) attributable to a parent enterprise. Other type of foreign investment is portfolio investment (shareholder investment in less than $10 \%$ of a company's capital) and bonds/loans are obtained from foreign banks. Foreign Direct Investment (FDI) is considered as one of the essential factors for overall development process of a developing country like Bangladesh. Industrial development is an important pre-requisite for economic growth of a developing country. Bangladesh is basically a country of agrarian economy. For her economic development, industrial economy is imperative. So Bangladesh is gradually moving from agrarian economy to industrial economy. In the age of globalization, it has become a burning issue to exchange views, ideas, capital and human resources. Government of Bangladesh is trying to create a favorable investment environment through introducing economic policies, incentives for investors, promoting privatization and so on. Therefore, the contribution of FDI is necessary in the enhancement of a country's economic growth. FDI stocks are the value of capital and reserves (including retained profit) attributable to a parent enterprise. Other type of foreign investment is portfolio investment (shareholder investment in less than $10 \%$ of a company's capital) and bonds/loans are obtained from foreign banks. The relationship between Foreign Direct Investment (FDI) and economic growth has been an interested issue for several decades. In the new growth theory, FDI is an important factor which contributes to economic growth through technology transfer efficiency improvement. FDI affects economic growth in several ways. It is argued that FDI has been a major channel for the access to advanced technologies by recipient countries and hence plays a central role in the technological progress of these countries (Borensztein, E., Gregorio, J.D. and Lee, J.W. (1998)). Findlay (1978) asserts that the host countries can benefit from the "contagion effect" associated with the 
advanced technology, management practices and marketing skills used by the foreign firms. Outputs from FDI activities are often exported mainly to third-country markets outside the host and source countries. As inputs, FDI activities have used capital goods and other intermediate inputs supplied by host and other foreign countries.

Thus FDI is associated with both import and export trade in goods, and the host country can benefit from an investment-led export growth. FDI is an agent for the transformation of both the host and source economics (Lyold, 1996). Multinational corporations (MNCs) have played a central role in developing the host countries' production capacities which are often directed towards export-oriented activities. As a result, FDI contributes to the transformation of the industrial structure of host economy and the commodity composition of its exports. The presence of foreign firms in the economy with their superior endowments of technology and management skills will expose local firms to fierce competition (Chen, C., Chang, L. and Zhang, Y (1995). Local firms may also be under pressure to improve their performance and to invest in research and development (R\&D). Thus FDI enhances the marginal productivity of the capital stock in the host economies and thereby promote growth (Wang and Blomstrom (1992). In addition, Lahiri and Ono (1998) observed that higher efficiency of foreign firms may help lower prices and hence increase consumers' surplus. Furthermore, FDI raises employment by either creating new jobs directly or using local inputs (creating more jobs indirectly).

According to Xiaoqin Fan and Paul M. Dickie (2000), FDI contributes to growth through several channels. It directly affects growth through being a source of capital formation. Capital formation refers to net additions to capital stock of an economy, including the creation of factories, new machinery and improved transportation. As a part of private investment, an increase in FDI will, by itself, contribute to an increase in total investment. An increase in investment directly contributes to growth. FDI also contributes to growth indirectly. FDI beneficially influences other macroeconomic variables, such as employment, export, consumption and saving. These, in turn, enhance growth. FDI not only affects the level of investment, but also the quality of investment. In the view of industrial organization theory of FDI (Hymer, 1976), MNCs face some disadvantages imposed by both geographic and cultural distances when competing with indigenous firms. To overcome these inherent disadvantages, MNCs must possess some kind of ownership advantage in order to compete with local firms. These ownership advantages can be expressed as technology, cost effectiveness, established market and financial strength. These advantages enable them to operate in a foreign market. As such, FDI also consist of a bundle of intangible assets, including capital, new technology, management skills and market channels. The inflow of FDI can therefore contribute to improved technology, equipment and infrastructure in host countries.

Related to the technological advantages of FDI is the benefit accruing to domestic firms through the "spillover effects" (Caves, 1974; Globerman, 1979; Blomstrom and Perrsion, 1983; Athukorala and Menon, 1996). When FDI flows into a host country, there is a potential for FDI to act as a vehicle through which new ideas, technologies, and best working practices can be transferred to domestic firms. During this process, domestic firms can gain through several channels. The technology of local firms may improve as foreign firms demonstrate new technologies, provide technological assistance to their local suppliers and customers and train workers whom local firms may later employ. Furthermore, the competitive pressures from foreign firms may force local firms to operate more efficiently and stimulate them to introduce new technologies. FDI also strengthens the capability of a host economy to reach international markets through its international links (Chia, 1995).

Many MNCs use global trading and distribution channels established by parent firms to produce capital goods and intermediate inputs and to export their products. Even though FDI augments growth through direct as well as indirect channels, it is difficult to quantitatively measure the contribution of FDI to growth. This is especially true for the indirect effects of FDI. FDI can contribute to the upgrading of the whole industrial structure of economies through affecting macroeconomic variables such as employment, exports, consumption and saving. All of these factors contribute to technological progress and efficiency improvement, not only stimulate economic growth, but also directly to raising living standards within host countries.

The relationship between FDI and economic growth has motivated much empirical literature focusing on both industrial and developing countries. Neoclassical models of growth as well as endogenous growth models provide the basis for most of the empirical work on the FDI-growth relationship. However, empirical evidence has shown that the effect of FDI on economic growth is dependent upon a set of conditions in the host country's or local economy, for example, the level of human capital, government policies, location and infrastructure. (Balasubramanyam, et al. (1996).

In the recent years, FDI policies has become one of the central economic policies for the developing countries, learned from the experiences of newly industrialized countries (NICs) like South Korea, Singapore, Hong Kong and Taiwan which promoted FDI as the catalyst of rapid economic growth in the early stage of their economic development. The relationship between FDI and economic growth is one of the well studied subjects in the field of development economics especially after the advent of endogenous growth model (Borenzteins, et al. 1995, Balasubramanyam, et al. 1996).

\section{Literature Review}

The subject of Foreign Direct Investment and growth had been presented in various studies. Some of these important empirical studies have been critically reviewed to develop 
objectives in the context of Bangladesh and, further, to analyze it to draw some important conclusions and policy recommendations. The massive literature on the role of FDI on economic growth has shown various types of effects such as positive, no effects or ambiguous in various countries. Agrawal et al. (2011) examined the effect of FDI for the time period of 1993-2009 on economic growth for China and India. They accumulated the modified growth model from the basic growth model. The factors integrated in growth model were GDP, Human Capital, Labor Force, FDI and Gross Capital Formation. After running OLS method of regression, they found that $1 \%$ increase in FDI would result in $0.07 \%$ increase in GDP of china and $0.02 \%$ increase in GDP of India. They also found that China's growth is more affected by FDI than India's growth. The majority of the foreign investors prefer china over India for investment because China has a bigger market size than India, offers easy accessibility to export market, government incentives, developed infrastructure, cost - effectiveness, and macro-economic climate.

Agama (2010) examined the impacts of exports and FDI on economic growth of South Asian countries namely Bangladesh, India, Pakistan and Sri Lanka. The study used secondary data ranging from 1980 to 2009 and simple log linear regression model. He found that the impacts of exports and FDI are statistically significant. He proposes that the policy makers of each country of South Asia should diversify the country's exports to enlarge exports volume and increase FDI inflows because it have the potential of accelerating economic growth in the future of South Asian economies.

Mallick and Moore (2008) estimated the endogenous growth model for 60 developing countries by using panel data during 1970-2003. They found that FDI inflows have a positive and significant effect on economic growth across all income groups. But the indirect impact of FDI on economic growth through their contribution to investment could be weaker in the lower income group countries. Chang (2007) used the ADF test, the Peron test, and Divot and Andrew's unit-root test to test the stationary of the variable in Taiwan. He applied the Johansen cointegration test, the multivariate error correction model, and the Granger causality test. He found that these are no causal relationship between FDI inflows and economic growth.

De Gregorio (2003) has noted that technologies and knowledge that are not readily available to host country, investors may be brought to them along with FDI and led to productivity growth. FDI may also bring in expertise that the country does not possess, and foreign investors may have access to global markets. In the empirical studies during the period 1950-1985, he found that increasing aggregate investment by 1 percentage point of GDP increased economic growth of Latin American countries by $0.1 \%$ to $0.2 \%$ a year. But increasing FDI by the same amount increased growth by $0.6 \%$ a year. This indicated that FDI is three times more efficient than domestic investment.

In contrast, Adam \& Tweneboah (2009), economists from Ghana, conducted an independent study on the FDI and stock market developments in the country conclude that FDI in Ghana had a positive impact on the development of the economy and the stock market. The examination included data of market capitalization as a proportion of the Local GDP and Ghanacedi and Dollar exchange and the net FDI influx of the quarters between the years 1991 to 2006. With the use of multivariate co-integration analysis and the Vector Error Correction Model., the study revealed that the relationship between FDI and the Ghanaian stock market will be beneficial in the long run for the country.

Braunstein and Epstein (2002) used a regression model with province-level panel data from 1986 to 1999. They found that FDI had crowded out domestic investment in China. They pointed out that benefits of FDI had almost disappeared as a result of intense competition of FDI among the regions in China, which has forced regions to reduce taxes, regulations on environmental protection, wages and working conditions.

Zhang (2001) tested the causality between FDI inflows and economic growth by using annual real FDI stock and real GDP data for 11 high-income and low-income developing countries in East Asia and Latin America. The Johansen cointegration test, the error-correlation model and the Granger causality test were applied. He concluded that the impact of FDI on host countries is country-specific. FDI inflows appeared to enhance growth in East Asian countries such as Taiwan. FDI tends to be more likely to promote economic growth when host countries adopt liberalize trade regime, improve education and human capital.

Ramirez (2000), his empirical works on Mexico supported the positive effect of FDI inflows on economic growth. He employed the Johansen cointegration test and the errorcorrection model for the period $1960-1995$. He showed that the growth rate of the private and foreign capital stock, as well as the export variable, have a positive and significant effect on the labor productivity growth rate.

\section{Objectives of the Study}

Foreign investment inflows to Bangladesh continued to increase over the last decade as a result of investment favorable policies adopted by the successive government. Since the beginning of the 90's decade, the annual value of FDI inflows to Bangladesh has started to continue with an increasing rate when compared to 80's decade. According to the previous literature the FDI inflows have a positive impact on economic growth of host countries. This paper focuses on the FDI-led growth hypothesis in the case of Bangladesh. Accordingly the main objectives are;

1. To examine long run association between FDI and economic growth of Bangladesh using cointegration estimation systems.

2. To utilize univariate ADF test to check for stationary and bivariate cointegration to check for long run relationship between two variables.

An infusion of FDI, while bringing the economy to a higher long run growth path raises growth in the short run as 
well. With increased growth in the short run, the economy can traverse along its transitional path.

\section{An Overview of FDI in Bangladesh}

Generally Bangladesh depends on 36 countries across the globe for FDI. Among the sources, 21 countries belong to the developing transition economics. In 2005, FDI has been originated from 30 different sources dominated by the developed economies (51.45\%) and a significant share of FDI also came from developing economies (43.23\%). As a developing country, Bangladesh needs FDI for its ongoing development process. Since independence, Bangladesh is trying to be a suitable location for FDI. However, the total inflow of FDI has been increasing over the years. In 1972, annual FDI inflow as US\$ 90000 US\$, and after 41 years, in 2012 annual FDI reached to US\$ 1178439622 (UNCTAD2005, Bangladesh Investment Handbook 2007- BOI). Contribution of FDI was not remarkable until 1980, a year of policy change. That year government enacted the 'Foreign Investment Promotion and Protection Act, 1980' with an attempt to attract FDI. Enacting the Act government opens all sectors for FDI other than defense equipment and machinery, nuclear energy, forestry in the reserved forest area, security printing and minting, and railways (Foreign Investment Promotion and Protection Act, 1980). The table shows a fluctuating trend of the FDI inflows over the last 15 years. Data shows that in 1999 there was a sudden fall in the FDI, and again in 2001, 2002 and 2003 the falling tend continued for many reasons.

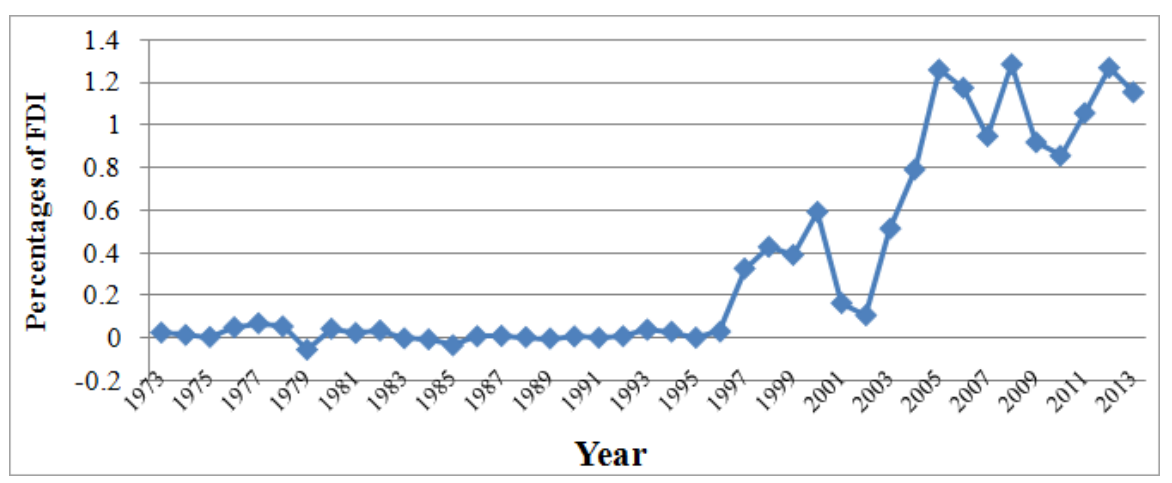

Source: The World Bank Indicator Index-2013

Figure 1. FDI Inflows as Percentages of GDP in Bangladesh.

Among others serious political unrest during the period was a major factor that discouraged foreign investment in these years and it took quite some time to regain the confidence of foreign investors. It stabilized afterwards but remained below the average achieved during 1997-2000. Later on during next two years period it becomes alive again. Figure 1 shows the foreign direct invest flow over the year 1973 to 2013 in Bangladesh as percentage of Gross Domestic Product. It is a matter of great concern that in spite of Bangladesh's comparative advantages in labor incentive manufacturing, adoption of investment friendly policies and regulations, establishment of EPZs in different suitable locations and other privileges, FDI flows have failed to be accelerated. However, the year 2005 and 2006 show a substantial improvement in FDI achievement.

\section{Empirical Methodology}

The present study uses time series data of foreign direct investment and gross domestic product (GDP) during the period 1973 - 2013 to investigate the relationship between foreign direct investment and economic growth. Data on foreign direct investment and gross domestic product have been collected from the Bangladesh Bureau of Statistics 2013, Economic Relations Division (ERD) 2010 Ministry of Finance, Government of Bangladesh, World Development indicator data base, World Bank 2013.
The first step, in our methodology, is to determine whether the variables used are stationary or not. If they are nonstationary in that case the issue is- to what degree they are integrated, and then test for cointegration among the variables. Error correction mechanism used to study the short run dynamic regulating relation between the variables. Finally, we test for Granger Causality among the variables in a VECM framework.

\subsection{Stationary Test}

Practically most econometric time series data shows trends and are non-stationary (Phillips, Perron, 1988). Any time series has a unit root where its first difference is stationary. Therefore, as first step in empirical analysis with any time series is to test for the presence of unit roots in order to remove the problem of spurious regression. In this stage, it is needed to explore the order of each variable to establish whether it contains unit roots and how many times it needs to be differenced to draw a stationary series.

To look at whether the data series are stationary, many types of tests can be performed like the Dickey - Fuller Test, the Augmented Dickey - Fuller (ADF) Test, and Phillips Perron Test. This study applies Augmented Dicky-Fuller (ADF) test, which is based on the following regression equation with a constant and a trend of the form: 


$$
\Delta Y_{t}=\delta_{1}+\delta_{2} t+\xi Y_{t-1}+\theta \sum_{i=1}^{m} \Delta Y_{t-i}+u_{t}
$$

Where, $\Delta Y_{t}=Y_{t}-Y_{t-1}$ and $Y$ is the variable under consideration, $m$ is the number of lags in the dependent variable, chosen by Schwartz Information Criterion (SIC) and $u_{t}$ are assumed to be identically and independently distributed random variable. This ADF test statistic checks the null hypotheses that the time series has a unit root, i.e., $\xi=0$ under the alternative hypotheses of stationary time series If the null hypothesis is rejected, then the series is stationary and no differencing in the series is necessary to induce stationary.

\subsection{Cointegration Test}

The cointegration test provides the long run relationship between non-stationary time series. The concept of cointegration was introduced by Granger (1981) and the statistical analysis of cointegrated process was organized by Engle and Granger (1987). Cointegration means that despite being individually non-stationary a linear combination of two or more time series can be stationary. When a linear combination of non-stationary variables is stationary, the variables are said to be cointegrated and the vector that defines the stationary linear combination is called a cointegrating vector. In this case, the variables are said to be cointegrated. Cointegration refers to a linear combination of non-stationary variables where all variables must be integrated of the same order. A necessary condition for cointegration is that the data series for each variable involved exhibit similar statistical properties, that is, to be integrated to the same order with linear combination of the integrated series.

There are two methods which are widely used for testing cointegration:

1. Engle-Granger Residual based ADF method.

2. Johansen Full Information Maximum Likelihood Method (Johansen 1988; Johansen and Juselius 1990).

\subsubsection{Engle-Granger Residual Based ADF Method}

Engle and Granger (1987) proposes alternative test for null hypothesis of no cointegration against the alternative of cointegration. It is a common practice to estimate a regression equation, obtain the residuals, and use ADF test. Engle and Granger propose the following modified form to test for the presence of unit root in the error term:

$$
\Delta \hat{u}_{t}=\alpha+\beta t+\gamma u_{t-1}+\sum_{i=1}^{k} \theta_{i} \Delta \hat{u}_{t-1}+v_{t}
$$

Where $\hat{u}_{t}$ is obtained from the cointegrating regression, $v_{t}$ is an identically and independently distributed error term with zero mean and constant variance $\sigma$.

\subsubsection{Johansen Full Information Maximum Likelihood Method}

Johansen (1988) suggests a maximum likelihood procedure to obtain cointegrating vectors and speed of adjustment coefficient of ECM. Identifying the number of cointegration vectors within the Vector Autoregressive (VAR) model is the basis for this procedure. To identify the number of cointegration vectors, a likelihood ratio test of hypothesis procedure is used. According to this procedure, it allows the estimation of all possible cointegrating relationships and develops a set of statistical tests to check the hypotheses about how many cointegrating vectors exists in the framework.

The following Vector Autoregressive (VAR) model is the basis of multivariate cointegration of Johansen Maximum Likelihood approach:

$$
Z_{t}=A_{1} Z_{t-1}+\ldots .+A_{k} Z_{t-k}+u_{t}
$$

Here $Z_{t}$ is an $(n \times 1)$ vector of $\mathrm{I}(1)$ variables including both endogenous and exogenous variables, $A_{i}$ is an $(n \times n)$ matrix of parameters, $u_{t}$ is $(n \times 1)$ vector of white nose errors. Each equation in (3) can be estimated by OLS because each variable in $Z_{t}$ regressed on the lagged values of its own and all other variables in the system.

Two Likelihood Ratio (LR) tests are formulated for detecting the presence of a single cointegrating vector.

Firstly, the trace test statistic is:

$$
\lambda_{\text {trace }}=-2 \ln Q=-T \sum_{i=r+1}^{p} \ln \left(1-\lambda_{i}\right)
$$

The trace statistics test the null hypothesis: "there are at most $r$, cointegrating relations" against the alternative of " $m$ cointegrating relation" where, $\mathrm{r}=0,1 \ldots \mathrm{m}-1$.

The second test is known as the maximum-eigenvalue test which is as follows:

$$
\lambda_{\max }=-2 \ln (Q: r / r+1)=-T \ln \left(1-\lambda_{r+1}\right)
$$

The maximum Eigen value statistics test the null hypothesis: "there are $\mathrm{r}$ cointegrating relations" against the alternative: "there are $r+1$ cointegrating relations". Monte Carlo has derived the critical values for these tests, stimulated and tabulated by Johansen (1988) and OsterwaldLenum (1992).

\subsection{Error Correction Mechanism}

The error correction mechanism first introduced by Sargan (1984) and later popularized by Engel and Granger (1987). Since variables in the growth model are cointegrated, an error correction representation would be a more appropriate modeling strategy to capture short-run and long-run dynamics in the model. When variables are cointegrated that is, $(1,1)$, there is a general and systematic tendency for the series to return to their equilibrium value. The Granger 
representation theorem states that if a set of variables is cointegrated $(1,1)$, implying that the residual of the cointegrating regression is of order $\mathrm{I}(0)$, then their exists an ECM describing that relationship. This theorem is a vital result as implies that cointegration and ECMs can be used as a unified empirical and theoretical framework for the analysis of both short-run and long-run behavior.

Let $Q_{a}$ and $Q_{p}$ variables are cointegrated, and then the relationship between the two can be expressed as ECM. Assuming that $Q_{a}$ "causes" of $Q_{p}$ and both variables are considered in logarithmic forms. The ECM can be written:

$$
\Delta \ln Q_{a t}=\alpha_{0}+\alpha_{1} \Delta \ln Q_{p t}+\alpha_{2} E C T_{t-1}+\varepsilon_{t}
$$

Where $\Delta$ as usual denotes the first difference operator and $\varepsilon_{t}$ is a random error term. The term $E C T_{t-1}$ is the one period error correction term from the cointegrating regression. The ECM equation states that $\Delta Q_{a}$ depends on $\Delta Q_{p}$, and also on the equilibrium error correction term (ECT). If the later is non-zero then the model is out of the equilibrium. Suppose $\Delta Q_{p}$ is zero and $E C T_{t-1}$ is positive. This means $\Delta Q_{a t}$ is above its equilibrium value. Since $\alpha$ is expected to be negative, the term $\alpha_{2} E C T_{t-1}$ is negative and therefore $\Delta Q_{a t}$ becomes negative to restore the equilibrium. That is, if $\Delta Q_{a t}$ is above its equilibrium value, it starts falling in the next period to correct the equilibrium error, hence the name ECM (Gujarati 1998:825). There are two characteristics of an ECM:

First, an ECM is dynamic in the sense that it involves lags of the dependent and explanatory variables. It thus captures the short-run adjustments to changes in to past disequilibrium and contemporaneous changes in the explanatory variables. Second, the ECM is transparent in displaying the cointegrating relationship between or among the variables.

\subsection{Granger Causality Test}

$$
\begin{gathered}
Y_{t}=\sum_{i=1}^{n} \alpha_{i} X_{t-i}+\sum_{j=1}^{n} \beta_{j} Y_{t-j}+u_{1 t} \\
X_{t}=\sum_{i=1}^{n} \lambda_{i} X_{t-i}+\sum_{j=1}^{n} \delta_{j} Y_{t-j}+u_{2 t}
\end{gathered}
$$

Where it is assumed that the disturbances $u_{1 t}$ and $u_{2 t}$ are uncorrelated. Equation (7) postulates that $Y$ is related to lag values of itself as well as lag values of $X$, and equation (8) postulates that $X$ is related to lag values of itself as well as lag values of $Y$. Now we distinguish four cases:

1. Unidirectional causality from $X$ to $Y$ is indicated if the estimated coefficients on the lagged $X$ in (7) are statistically different from zero as a group (i.e., $\left.\sum \alpha_{i} \neq 0\right)$ and the set of estimated coefficients on the lagged $Y$ in (8) is not statistically different from zero (i.e., $\sum \delta_{i} \equiv 0$ ).

2. Unidirectional causality from $Y$ to $X$ exists if the set of lagged $X$ coefficients in (7) is not statistically different from zero (i.e., $\sum \alpha_{i}=0$ ) and the set of lagged $Y$ coefficients in (8) is statistically different form zero (i.e., $\sum \delta_{i} \neq 0$ )

3. Bilateral causality is suggested when the sets of lagged $X$ and $Y$ coefficients are statistically significantly different from zero in both regressions.

4. Finally, independence is suggested when the sets of lagged of $X$ and $Y$ coefficient are not statistically significant in both regressions.

More generally, since the future cannot predict the past, if variable $X$ Granger causes variable $Y$, then changes in $X$ should precede changes in $Y$. Therefore, in a regression of $Y$ on the other variables (including its own past values) of $X$ and it significantly improves the prediction of $Y$, then we can say that $X$ causes $Y$. A similar definition applies if $Y$ Granger causes $X$.

\section{Result Analysis}

This study uses time series data of foreign direct investment and gross domestic product (GDP) during the period 1973 - 2013 and data have been collected from various secondary sources such as Bangladesh Bureau of Statistics 2013, Economic Relations Division (ERD) 2013, Ministry of Finance, Government of Bangladesh, World Development indicator data base, World Bank 2013.

Table 1 shows the basic characteristics of the collected data, which is in general called as the descriptive statistics of the data.

Table 1. Descriptive Statistics of the Data on Variables.

\begin{tabular}{llllll}
\hline Variables & Mean & Max. & Min. & SD & Variance \\
\hline GDP & 39385.9278 & 116355.06 & 6288.25 & 28015.94222 \\
FDI & 208.7050 & 1178.44 & .09 & 341.38973 \\
\hline
\end{tabular}

Source: Author's own calculation

From Table 1, it is found that average annual GDP in Bangladesh is US\$ 39385.9278 million with maximum US\$ 116355.06 million and minimum US\$ 6288.25 million. There is a significant gap between these two margins. The standard deviation and variance of GDP are 16506.56 and
272466409 respectively. The average annual foreign direct investment inflow in Bangladesh is US\$ 208.7050 million with maximum US\$ 1178.44 million and minimum US\$ 0.09 million. The standard deviation and variance of foreign direct investment in Bangladesh are 341.38973 and 784893018.498 respectively. 


\subsection{Testing for Stationarity}

We used unit root test to check whether our variables (Foreign Direct Investment - FDI and Gross Domestic
Product - GDP) are non-stationary. Both the variables are used in logarithmic form $(\ln G D P$, and $\ln F D I)$. The result is also further justified by Phillips-Perron (PP) Test. The results of these tests are presented in the Table 2.

Table 2. Unit root test.

\begin{tabular}{lcccccc}
\hline \multirow{2}{*}{ Variable } & \multicolumn{3}{c}{ ADF } & \multicolumn{2}{c}{ PP } \\
\cline { 2 - 7 } & Level & First Difference & Critical Values & Level & First Difference & Critical Values \\
\hline $\ln G D P$ & -0.238 & $-5.676^{* * *}$ & $-3.62(1 \%)$ & -1.345 & $-5.116^{* * *}$ & $-3.62(1 \%)$ \\
$\ln F D I$ & -1.806 & $-7.752^{* * *}$ & $-2.94(5 \%)$ & -1.70 & $-8.213^{* * *}$ & $-2.94(5 \%)$ \\
\hline
\end{tabular}

Note: Superscripts***,** and $*$ indicate rejection of null hypothesis at $1 \%, 5 \% \& 10 \%$ level of significance respectively.

Table 2 reveals that the time series $\ln G D P$ and $\ln F D I$ are non stationary i.e. I(0) at their levels, while first difference made them stationary. Thus, we conclude that the variables are non-stationary and it is integrated of order one I(1). Both the ADF and the PP test provide the same result.

\subsection{Testing for Cointegration}

\subsubsection{Result of Engle-Granger Residual Based ADF Method}

According to Engle- Granger residual based ADF method as proposed by Engle and Granger (1987), the test method and process is as follows:

First step, equation estimating using Ordinary Least Square (OLS) method:

$$
\ln G D P=\alpha+\beta \ln F D I+u_{t}
$$

If $\hat{\alpha}$ and $\hat{\beta}$ are the estimation values of regression coefficients, the estimated value of model residual may be expressed as:

$$
\hat{u}_{t}=\ln G D P-\hat{\alpha}-\hat{\beta} \ln F D I
$$

Second step, cointegration test of error series $\left(\hat{u}_{t}\right) \cdot \hat{u_{t}}$ is n-order integrated series if $\hat{u}_{t}$ is stationary series after $\mathrm{n}$ difference, and it may be regarded that there is cointegration relation between time series of $\ln G D P$ and $\ln F D I$. The following regression results can be obtained after analyzing the actual annual data of gross domestic product ( GDP) and foreign direct investment ( $F D I$ ) from 1973 to 2013 with Eviews software according to the above method.

After regressed $\ln G D P$ on $\ln F D I$, we obtain the following outputs:

So, our estimated regression model is

$$
\ln G D P=5.32+0.70 \ln F D I
$$

Since $\ln G D P$ and $\ln F D I$ are individually non-stationary, there is the possibility that this regression is spurious. But when we performed a unit root test on the residuals obtained

\begin{tabular}{|c|c|c|c|c|}
\hline \multicolumn{5}{|c|}{ Dependent Variable: $\ln G D P$} \\
\hline \multicolumn{5}{|c|}{ Method: Least Squares } \\
\hline \multicolumn{5}{|c|}{ Sample: 19732013} \\
\hline \multicolumn{5}{|c|}{ Included observations: 41} \\
\hline Variable & Coefficient & Std. Error & t-Statistic & Prob. \\
\hline $\mathrm{C}$ & 5.32 & 0.97 & 5.49 & 0.0000 \\
\hline $\ln F D I$ & 0.70 & 0.14 & 5.17 & 0.0000 \\
\hline R-squared & 0.92 & \multicolumn{2}{|c|}{ Mean dependent variable } & 10.32 \\
\hline Adjusted R-squared & 0.91 & S.D. depe & lent variable & 0.46 \\
\hline
\end{tabular}
from equation (10), we obtained the following results.
Table 3. Ordinary Least squares (OLS) output.

\begin{tabular}{|c|c|c|c|}
\hline \multicolumn{4}{|c|}{ Null Hypothesis: RES1 has a unit root } \\
\hline \multicolumn{4}{|c|}{ Lag Length: 0 (Automatic based on SIC, MAXLAG=9) } \\
\hline & & t-Statistic & Prob.* \\
\hline $\begin{array}{l}\text { Augmented Dickey } \\
\text { (Constant and Tren }\end{array}$ & ler test statistic & -4.66 & 0.0032 \\
\hline Test critical values: & $\begin{array}{l}1 \% \text { level } \\
5 \% \text { level } \\
10 \% \text { level }\end{array}$ & $\begin{array}{l}-4.22 \\
-3.53 \\
-3.20\end{array}$ & \\
\hline
\end{tabular}

Table 4. ADF Unit Root Test of OLS Residual.

*MacKinnon (1996) one-sided p-values.

The computed Augmented Dickey-Fuller test statistic (4.66) at constant and trend is much more negative than the critical values $[1 \%$ level $(-4.22), 5 \%$ level $(-3.53)$ and $10 \%$ level $(-3.20)$ ] and our conclusion is that the residuals from the regression of $\ln G D P$ on $\ln F D I$ are integrated of order zero i.e. $\mathrm{I}(0)$, that is they are stationary. Hence, the equation (10) is a cointegrating regression and this regression is not spurious, even though individually the two variables are nonstationary.

To sum up, our conclusion based on the result of EngleGranger residual based ADF method, is that $\ln G D P$ and ln FDI are cointegrated. Although they individually exhibit random walks, there seems to be a stable long-run relationship between them; they will not wander away from each other.

\subsubsection{Result of Johansen Full Information Maximum Likelihood Method}

The trace statistics test the null hypothesis: "there are at most $r$, cointegrating relations" against the alternative of " $m$ cointegrating relation" where, $r=0,1, \ldots \mathrm{m}-1$.

The maximum Eigen value statistics test the null 
hypothesis: "there are $r$ cointegrating relations" against the alternative: "there are $r+1$ cointegrating relations".

Table 5. Results of trace test.

\begin{tabular}{llllllll}
\hline Rank & Null & Alt. & Eigen value & Trace Statistic & 5 Percent Critical Value & 1 Percent Critical Value & Decision \\
\hline 0 & $\mathrm{r}=0$ & $\mathrm{r} \leq 1$ & 0.44 & 20.46 & 12.53 & 16.31 & None ** \\
1 & $\mathrm{r} \leq 1$ & $\mathrm{r}=2$ & 0.04 & 1.37 & 3.84 & 6.51 & At most 1 \\
\hline
\end{tabular}

Note: $*(*)$ denotes rejection of the hypothesis at the $5 \%(1 \%)$ level.

Table 6. Result of max-eigen value test.

\begin{tabular}{llllllll}
\hline Rank & Null & Alt. & Eigen value & Max-Eigen Statistic & 5 Percent Critical Value & 1 Percent Critical Value & Decision \\
\hline 0 & $\mathrm{r}=0$ & $\mathrm{r}=1$ & 0.44 & $19.09^{* *}$ & 11.44 & 15.69 & None \\
1 & $\mathrm{r} \leq 1$ & $\mathrm{r}=2$ & 0.040 & 1.37 & 3.84 & 6.51 & At most 1 \\
\hline
\end{tabular}

Note: $*(*)$ denotes rejection of the hypothesis at the $5 \%(1 \%)$ level

The Max-Eigen value and Trace statistic test reject the hypothesis of no cointegration and indicate that there is one cointegrating equation at the $5 \%$ and $1 \%$ significance level. So there is a long run relationship between gross domestic product and foreign direct investment in Bangladesh. It is standard practice to normalize the cointegrating vector with respect to the variable of interest to get a better interpretation. Since we are interested in analyzing the impact of foreign aid on economic growth, the cointegrating vector is normalized with respect to gross domestic product.

Table 7. Normalized cointegrating coefficients.

\begin{tabular}{ll}
\hline Estimated Equation: & $\beta_{1} \ln G D P+\beta_{2} \ln F D I=0$ \\
\hline Variables & Normalized Cointegrating Coefficients \\
\hline $\ln G D P$ & 1.00 \\
$\ln F D I$ & $-1.23(0.05)$ \\
\hline
\end{tabular}

Note: the value of parentheses indicated standard error

The normalized cointegration coefficients are shown in Table 7 and the signs of the variables confirm that there is a positive relationship between the variables.

\subsection{Error Correction Mechanism}

From the cointegration test we found that $\ln G D P$ and $\ln F D I$ are cointegrated; that is, there is a long run relationship between the two. Of course, in the short run there may be disequilibrium. There for we can treat the error term $\hat{u}_{t}$ in equation (10) as the "equilibrium error" and we can use this error term to tie the short run behavior of $\ln G D P$ to its long run value.

For our study the error correction model can be estimated as follows:

$$
\begin{aligned}
\Delta \ln G D P_{t} & =0.052-0.056 \Delta \ln F D I_{t}+0.01 \hat{u}_{t-1} \\
\mathrm{t} & =(5.23)
\end{aligned}
$$

R-squared $=0.54$; Durbin-Watson stat $=1.89$;

The coefficient of error correction is positive which accord $\ln G D P$ is below its equilibrium value and will cause $\Delta \ln G D P_{t}$ to be positive, leading $\ln F D I_{t}$ to rise in period $\mathrm{t}$.

The coefficient of $\hat{u}_{t-1}$ reflects the adjustment of departing from long run equilibrium, and indicates the adjustment of foreign direct investment and unbalance error of gross domestic product in former year to the economic growth in this year with 0.012 ratio. The absolute value of error correction coefficient is relatively small, which shows the departure of short run fluctuation to long run equilibrium is slight and the adjustment extent is small, and indicates that the promoting effect of foreign aid on gross domestic product is relative stationary in Bangladesh at present.

There is a negative relationship between short run adjustment of foreign direct investment and short run adjustment of gross domestic production, since the sign of the elastic coefficient is negative. But the sign of elastic coefficient $(-0.056)$ is too small. So we conclude that the positive long run effect between foreign aid and economic growth does not affect by this poor negative elasticity and foreign aid should increase to restore the equilibrium in the period $t$.

\subsection{Granger Causality Test}

There is a cointegration relation between foreign direct investment and gross domestic product or these two variables have long run equilibrium relation. The next step is to investigate the short-run dynamics via the analysis of Granger Causality tests. Granger causality test of these two variables is needed to make sure whether this long run equilibrium relation is causality, or whether foreign direct investment promotes economic growth and economic growth drives foreign direct investment or both exist.

F statistics and its corresponding probability used for rejecting of accepting the null hypothesis. The present study posses two null hypothesis:

a) $\ln$ FDI does not Granger Cause $\ln$ GDP

b) $\ln G D P$ does not Granger Cause $\ln F D I$

The results of the Granger causality are shown in the following Table 8 . 
Table 8. Results of Granger Causality.

\begin{tabular}{lllll}
\hline Null Hypothesis: & Lags & F-Statistic & Probability & Decision \\
\hline $\ln F D I$ does not Granger Cause $\ln G D P$ & 4 & 0.87134 & 0.4934 & Don't reject \\
$\ln G D P$ does not Granger Cause $\ln F D I$ & 4 & 0.73733 & 0.5744 & Don't reject \\
\hline
\end{tabular}

These results suggest that there is bilateral causality from FDI to GDP growth and vice versa.

\section{Conclusions and Policy Implication}

FDI has been revealed as an engine of economic growth. Apparently, the enormous potentials of FDI for speeding up the pace of economic advancement of Bangladesh cannot be overstated. The present study has evaluated the impacts of foreign direct investment on economic growth in Bangladesh. In Bangladesh, foreign direct investment as a percentage of GDP has slowly incresed rather than expectation. This study, therefore, strived investigate the long run impacts of foreign direct investment in the case of Bangladesh employing a time series econometric approach. From the stationary test both Augmented Dickey-Fuller (ADF) and Phillips-Perron (PP) unit root test suggests that the time series data are nonstationary but when their first difference is taken, they become stationary. Thus, they are integrated of order I $(1)$. The results of cointegration test - both Engle-Granger residual based ADF method and Johansen Full Information Maximum Likelihood method suggests that there is a positive long run relationship between the variables. From the error correction mechanism, the absolute value of error correction coefficient is relatively small, thus the departure of short run fluctuation to long run equilibrium is slight and the adjustment extent is small, and indicates that the promoting effect of foreign direct investment on gross domestic product is relative stationary in Bangladesh at present. At the end, the result of Granger causality test advocates two way causality from foreign direct investment to gross domestic product.

Foreign direct investments accommodate for job creation requirements, income generation, utilize national savings productively and facilitate the process of economic growth. FDI has been traditionally found to assist attract skilled labor, entrepreneurship, technological know-how and direct flow of foreign resources including foreign exchange. These factors increase the existing domestic resource base and promote growth when they flow into the economy. An export-led growth path, particularly at the initial stage of growth, in the later period, dependence on FDI might be realistic option. This finding can be the exports promotion incentives determine a specialization of the economy accompanied by the scale benefices. The exports may stimulate the country to import high-value inputs, products and technologies. By consequence, these elements may have a beneficial impact on the productive capacity of the economy. Bangladesh is highly populated country but its working population is uneducated and untrained, most of them work in agriculture sector. This sector requires a grand amount of foreign direct investment so, encouraging opportunities should be originated to attract the domestic and foreign investors. The most part of the
Banglaseh's economy is footing on the agriculture sector which itself not well-productive. A large amount of FDI could be attracted in food processing, agriculture services, machinery and other modern agricultural technology. FDI is rapidly diminishing in recent years. To increase the percentage of FDI inflow political condition of the country must be sound and stable. Consequently, the paper suggested the need for maintaining a steady economic growth and low inflation, increased investment in human capital expansion to make the stock of capital available in the country, the need to overhaul curtail widespread tax evasion, corruption and poor quality services; and the need to increase national savings and investments. These are necessary as catalysts to enhance economic growth in Bangladesh.

\section{References}

[1] Adams, S., 2009, Foreign direct investment, domestic investment and economic growth in Sub-Saharan Africa, Journal of Policy Modeling, 31: 939-949.

[2] Agrawal, G. and A. Khan, 2011, Impact on FDI on GDP: A Comparative Study of China and India, International Journal of Business and Management, 6(10): 71-79.

[3] Athukorala, P. and J. Menon (1996). "Foreign Investment and Industrialization in Malaysia: Exports, Employment and Spillovers". Asian Economic Journal 10(1): 29-44.

[4] Alam, M.S. and M. Zubayer, 2010. Intra Regional Foreign Direct Investment (FDI) Prospect in South Asian Association of Regional Cooperation (SAARC) Region, International Journal of Economics and Finance, 2: 3.

[5] Azam, Muhammad (2010). "An Empirical Analysis of the Impacts of Exports and Foreign Direct Investment on Economic Growth in South Asia". Interdisciplinary Journal of Contemporary Research Business, 2(7): 249-58.

[6] Balasubramanyam, V.N., Salisu, M. and Sapsford, D. (1996) "Foreign Direct Investment and Growth in EP and IS Countries". Economic Journal, 106: 92-105.

[7] Blomstrom, M. and H. Perssion (1983). "Foreign Investment and Spillover Efficiency in an Underdeveloped Economy: Evidence from the Mexican Manufacturing Industry”. World Development 11: 493-501.

[8] Braunstein, E. and Epstein G. (2002). "Bargaining Power and Foreign Direct Investment in China: Can 1.3 Billons Consumers Tame the Multinationals?" CEPA Working Paper 2002/13. New York: Center for Economic Policy Analysis.

[9] Borensztein, E., Gregorio, J.D. and Lee, J.W. (1998), "How Does Foreign Direct Investment Affect Economic Growth"? Journal of International Economics, 4: 115-35.

[10] Caves, R.E. (1974). "Multinational Firms, Competition and Productivity in Host Country" Economica 41: 176-93. 
[11] Chang, Shu Chen (2007). “The Interactions among Foreign Direct Investment, Economic Growth, Degree of Openness and Unemployment in Taiwan," Applied Economics 39: 164761.

[12] Chen, C., Chang, L. and Zhang, Y. (1995), "The Role of Foreign Direct Investment in China's Post 1978 Economic Development". World Development 23: 691-703.

[13] Chia, Siow Yue (1995). "The International Procurement and Sales Behavior of Multinational Enterprise". In Corporate Links and Foreign Direct Investment in Asia and the Pacific, edited by Edward Chen and Peter Dry dale. NSW: Harper Educational.

[14] De Gregorio, Jose. (2003), "The Role of Foreign Direct Investment and Natural Resources in Economic Development". Working Paper No. 196. Central Bank of Chile, Santiago.

[15] Dickey, D. A., Jansen, D. W. and Thornton, D. C. (1991). "A Primer on Cointegration with An Application to Money and Income", Review Federal Reserve Bank of ST. Louis, 73 (2), 58-78.

[16] Globerman, S., (1979). "Foreign Direct Investment and 'Spillover' Efficiency Benefits in Canadian Manufacturing Industries". Canadian Journal of Economics 12: 42-56.

[17] Granger, C. W, J. (1980) Long memory relationships and the aggregation of dynamic models. Journal of Econometrics. 14, 227-38.

[18] Granger, C. W. J. (1969). Investigating causal relations by econometric models and cross-spectral methods. Econometrica, 35, 424-438.

[19] Granger, C.W. J., 1981. Some properties of time series data and their use in econometric model specification. Journal of Econometrics 16, 121-30.

[20] Hassan and Kalim, 2012. The Triangular Causality among Education, Health and Economic Growth: A Time Series Analysis of Pakistan Muhammad Shahid Hassan and Rukhsana Kalim World Applied Sciences Journal, 18(2): 196207.

[21] Hoang, Thi Thu, Wiboonchutikula Paitoon and Tubtimtong Bangorn. (2010). "Does Foreign Direct Investment Promote Economic Growth in Vietnam?" Asean Economic Bulletin, 27(3): 295-311.
[22] Hymer, S., (1972). "The MNC and the Law of Uneven Development" in J.N. Bhagwati (ed), Economics and World Order, New York: MacMillan.

[23] Johansen, S., 1988. Statistical analysis of cointegration vectors, Journal of Economic Dynamics and Control, 12: 231-54.

[24] Johansen, S., 1991. Estimation and hypothesis testing of cointegration vectors in Gaussian vector on Economic autoregression models, Econometrica, 59: 1551-80.

[25] Kim, D.D. and Seo, J.S. (2003). "Does FDI Inflow Crowd Out Domestic Investment in Korea". Journal of Economic Studies 30 (6): 605-22.

[26] Lahiri, S. and Ono, Y. (1998). "Foreign Direct Investment, Local Content Requirement and Profit Taxation".Economic Journal 108: 444-57.

[27] Lyold, P. (1996), "The Role of Foreign Investment in the Success of Asian Industrialization". The China Quarterly 144: 1065-82.

[28] Mallick, Sushanta and Tomroe Moore (2008). "Foreign Capital in a Growth Model" Review of Development Economics 12: 143-59.

[29] Perron, P., 1991. Testing Consistency with Varying Sampling Frequency. Econometric Theory 7, 341-68

[30] Ramirez, Miguel D (2000). "Foreign Direct Investment in Mexico: A Cointegration Analysis, "Journal of Development Studies 37: 138-62.

[31] Wang, J. and Blomstrom, M. (1992). "Foreign Direct Investment and Technology Transfer: A Simple Model", European Economic Review 36: 137-55.

[32] Xiao, Qin Fan and Paul M. Dickie (2000). "The Contribution of Foreign Direct Investment to Growth and Stability". ASEAN Economic Bulletin 17(3): 312-23.

[33] Zhang, Kevin Honglin (2001). "Does Foreign Direct Investment Promote Economic Growth? Evidence from East Asia and Latin America". Contemporary Economic Policy 19: 175-85. 